\title{
A Study for the Use of Solar Energy for Agricultural Industry - Solar Drying System Using Evacuated Tubular Solar Collector and Auxiliary Heater -
}

\author{
Gwi Hyun Lee ${ }^{1 *}$ \\ ${ }^{1}$ Department of Biosystems Engineering, Kangwon National University, Chuncheon, Korea \\ Received: February $4^{\text {th }}, 2013$; Revised: February $14^{\text {th }}, 2013$; Accepted: February $19^{\text {th }}, 2013$
}

\section{Abstract}

Purpose: The objectives of this study were to construct the solar drying system with evacuated tubular solar collector and to investigate its performance in comparison with indoor and outdoor dryings. Methods: Solar drying system was constructed with using CPC (compound parabolic concentrator) evacuated tubular solar collector. Solar drying system is mainly composed of evacuated tubular solar collector with CPC reflector, storage tank, water-to-air heat exchanger, auxiliary heater, and drying chamber. Performance test of solar drying system was conducted with drying of agricultural products such as sliced radish, potato, carrot, and oyster mushroom. Drying characteristics of agricultural products in solar drying system were compared with those of indoor and outdoor ones. Results: Solar drying system showed considerable effect on reducing the half drying time for all drying samples. However, outdoor drying was more effective than indoor drying on shortening the half drying time for all of drying samples. Solar drying system and outdoor drying for oyster mushroom showed the same half drying time. Conclusions: Oyster mushroom could be dried easily under outdoor drying until MR (Moisture Ratio) was reached to about 0.2. However, solar drying system showed great effect on drying for most samples compared with indoor and outdoor dryings, when MR was less than 0.5 .

Keywords: Drying characteristics, Half drying time, Solar drying system, Solar collector

\section{Introduction}

In recent decades, there has been an increasing interest in the use of solar energy to decrease conventional energy consumption in many heat applications. The greatest advantage of solar energy as compared with other forms of energy is that it is clean and it can be supplied without any environmental pollution. Over the past century fossil fuels have provided most of our energy because there are much cheaper and more convenient than energy from alternative energy sources, and until recently environmental pollution has been of little concern.

Environmental problem is induced due to a combination of several factors such as the increases of the world

\footnotetext{
* Comesponding author: Gwi Hyun Lee

Tel: +82-33-250-6495; Fax: +82-33-255-6406

E-mail: ghlee@kangwon.ac.kr
}

population, energy consumption and industrial activities. Achieving solutions to environmental problems that humanity faces today requires long-term potential actions for sustainable development. In this respect, renewable energy resources appear to be one of the most efficient and effective solutions. The most important benefit of renewable energy systems is the decrease of environmental pollution. This is achieved by the reduction of air emissions due to the substation of electricity and conventional fuels.

The renewable energy technologies produce marketable energy by converting natural phenomena into useful forms of energy. One of these technologies is to use solar energy. Researches of solar energy have been carried out during the last decade including solar dryers (Basunia and Abe, 2001; El-Sebaii et al., 2002; Midilli and Kucuk, 2003). Energy conversion systems based on solar thermal 
technologies appeared to be cost effective compared to petroleum oil. In addition, solar thermal systems are non-polluting and can offer a beneficial impact on the environmental, economic, and potential issues of the world. The reduction of greenhouse gases pollution is the main advantage of utilizing solar energy. Therefore, solar thermal systems can be used to achieve a sustainable future.

Solar collector is the equipment for collecting solar energy efficiently. Solar collectors are one kind of heat exchangers that transform solar radiation energy to internal energy of the transport medium. Common uses in solar thermal applications are flat plate and evacuated tubular solar collectors. It has been known that evacuated tubular solar collectors have better performance than flat-plate ones, in particular for high temperature operations. Evacuated tubular solar collectors collect both direct and diffusion radiation. However, their efficiency is higher at low incidence angle, which gives them an advantage over flat plate ones in day-long performance.

Evacuated tubular solar collectors minimize convective heat loss by placing the solar absorbing surface in a vacuum. These result in good performance at high temperature. Evacuated tube solar collectors based on single envelope vacuum tubes with heat-pipe removal have been commercialized in Europe, and glass evacuated tubes with U-tube heat removal system have been produced in Japan (Morrison et al., 2004). A large number of variations of the absorber shape for evacuated tube solar collectors are on the market (Lin and Furbo, 1998). Production of all-glass evacuated tubes in China was estimated to be more than 20 million tubes per years in 2001 (Morrison et al., 2004). Evacuated tubes with CPC reflectors are also commercialized by several manufactures. A Dewar type with two concentric glass tubes is also used and the space in the tubes is evacuated as vacuum jacket. The advantage of this type is that it is made entirely of glass and it is not necessary to penetrate the glass envelope in order to extract heat from the tube, and thus leakage losses are not present. In addition, it is also less expensive than the single envelop system (Morrison, 2001).

A variety of agricultural products are dried as a means of preservation. Solar drying, which is a traditional drying technique in many countries, produces a product with desirable properties in color, flavor, and texture, etc. However, it also has many disadvantages, such as low drying rate, exposure to contamination from dust and insects, etc. To overcome these problems, it is necessary to use other alternative drying methods. It is obvious that an artificial drying is more efficient than a natural sun drying in reducing the drying time with better quality of product. Many types of dryer are available for drying agricultural products. However, most of commercial dryers has disadvantage in consuming a lot of energy. Consumption energy for drying is dependent on the type of dryer, drying conditions, and agricultural products. Usually, energy required for drying of agricultural products is in the range of 3,300 kJ/kg 8,000 kJ/kg (Bakker-Arkema et al., 1999). In particular, developed countries use between $7 \%$ and $15 \%$ of the industrial energy in drying (Keey, 1992). Solar energy has been noticed as an important alternative source of energy. It is preferred to other sources of energy because it is abundant, inexhaustible, and nonpolluting. It can be tapped at relatively low cost and has no associated environmental dangers. Therefore, the agriculture producer may want to use improved solar drying system in saving the energy. Energy consumption of solar dryer is very low in compared with most of commercial dryers, because solar dryer only requires energy to operate fan and/or auxiliary heat source. Thus, the use of solar dryer can reduce an amount of energy required for drying of agricultural products.

Therefore, the objectives of this study were to construct the solar drying system with evacuated tubular solar collector and to investigate its performance in comparison with indoor and outdoor dryings.

\section{Material and Methods}

\section{Drying system}

Drying system consists of the evacuated tubular solar collector with CPC reflector, storage tank, water-to-air heat exchanger, auxiliary heater, and drying chamber (Figure 1). In this system, water was used as heat transfer fluid. It is indirect air heating systems that circulate water via pipeline through evacuated tubular solar collector to water-to-air exchanger.

During the day time, the solar drying system absorbs solar radiation with collector and conveys it to storage tank using water. As the drying system is operated, ambient air is supplied by the fan and heated up in the water-to-air heat exchanger. The heated air is forced to enter in the drying chamber from the bottom of the tray 


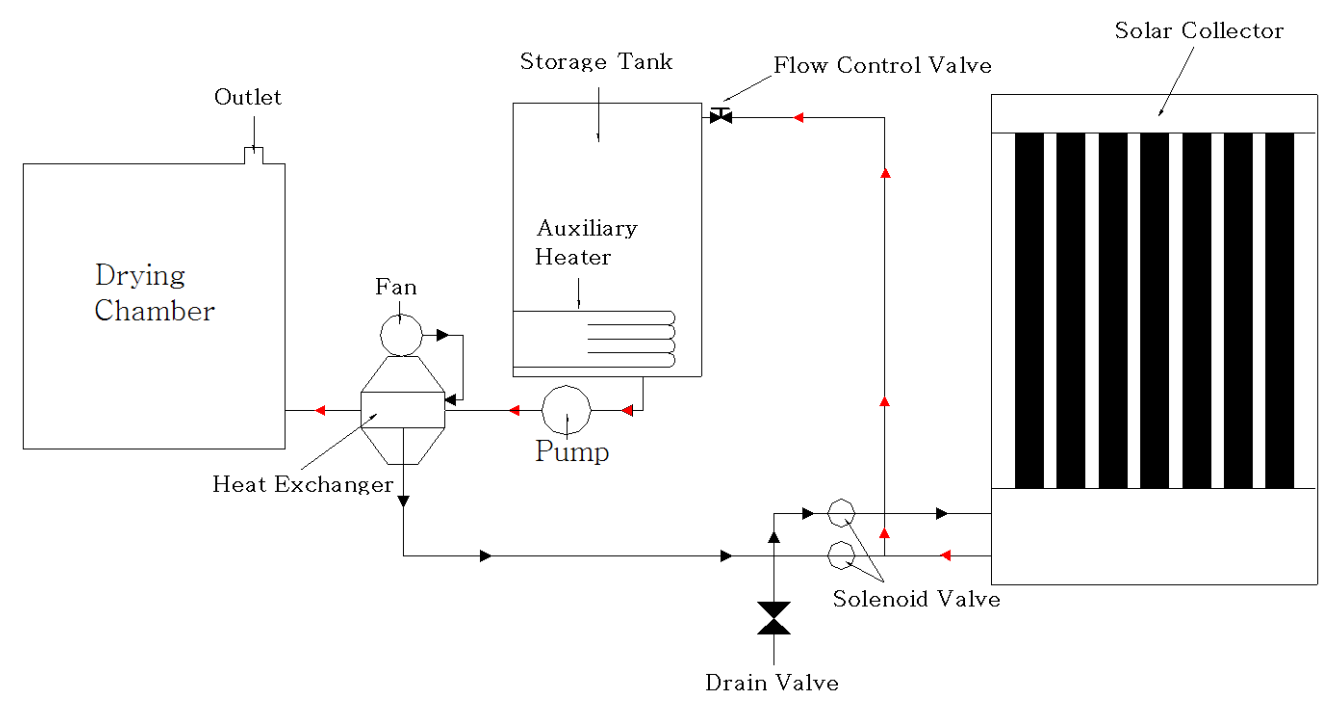

Figure 1. Schematic diagram of the solar drying system using evacuated tubular solar collector.

\begin{tabular}{|c|c|c|}
\hline \multicolumn{2}{|c|}{ Material } & Pyrex borosilicate glass \\
\hline \multicolumn{2}{|c|}{ Expansion coefficient } & $3.3 \times 10^{-8}$ \\
\hline \multicolumn{2}{|c|}{ Absorbance } & $\geq 95 \%$ \\
\hline \multicolumn{2}{|c|}{ Emission } & $<5 \% \mathrm{~W} /\left(80^{\circ} \mathrm{C}\right)$ \\
\hline \multicolumn{2}{|c|}{ Coefficient of average heat loss } & $<0.5 \mathrm{~W} /\left(\mathrm{m}^{\circ} \mathrm{C}\right)$ \\
\hline \multicolumn{2}{|c|}{ Vacuum } & $\mathrm{P}<5 \times 10^{-3} \mathrm{~Pa}$ \\
\hline \multicolumn{2}{|c|}{ Maximum strength } & $0.8 \mathrm{MPa}$ \\
\hline \multirow{2}{*}{ Size } & Outer tube & $\varnothing 47$ L1, 200 \\
\hline & Inner tube & $\varnothing 37$ L1, 200 \\
\hline \multicolumn{2}{|c|}{ Absorber coating } & Al-N/Al selective coating \\
\hline
\end{tabular}

and flow upward through the sample and finally through the outlet. Also, water in the storage tank is forced by pump to heat exchanger and then circulated through the closed solar collector loop. If solar energy is not available in night time or cloudy day, water is circulated to storage tank with bypassing the solar collector using a solenoid valve. Subsequently, auxiliary heater inside the storage tank is turned on to heat water. Capacity of auxiliary heater was 2 $\mathrm{kW}$ and fixed at the bottom part of storage tank.

Solar collector in this study is based on eight parallel connected double glass tubes, which are open at one end. The tubes are annuli with closed end and the outside of the inner glass wall is treated with absorbing selective coating. Each glass tube is connected to two manifold pipes, which are placed in an insulated PVC duct. An end of feed tube is connected to a manifold pipe and another end is opened for circulating heat transfer fluid inside the inner glass tube. The heat transfer fluid from one of

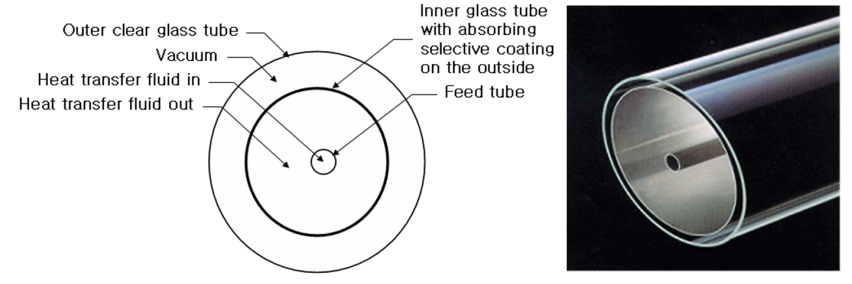

Figure 2. Evacuated double glass tube.



Figure 3. Solar collection principle of CPC-reflector. .

manifold pipe is flowed up from bottom to top of the inside of the feed tube and flowed down along outside of the feed tube inside the inner glass tube into another manifold pipe. It ensures a high heat transfer coefficient from the inner glass tube to the collector fluid. Table 1 presents the characteristics of evacuated double glass tube used in this study. Figure 2 shows the design of the evacuated double glass tube. CPC-reflectors installed under each evacuated glass tubes have an angular response which fully characterizes their optical behavior (Figure 3): they accept all incoming radiation within their 


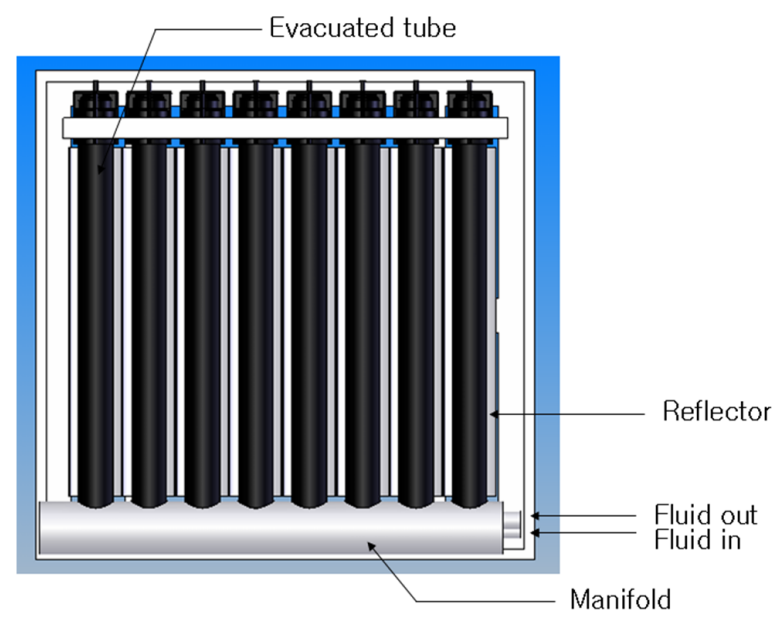

Figure 4. Evacuated tubular solar collector with CPC-reflector.

design acceptance angle and none outside of it (Carvalho et al., 1995). Figure 4 presents the evacuated tubular solar collector with CPC-reflectors. Total area of solar collector used in this study was $1.5 \mathrm{~m}^{2}$.

\section{Drying experiments}

Drying experiments were carried out using the developed solar drying system on the typical days in fall (from 13:00 to 21:00 of October). Ambient air temperature and drying air temperature inside the chamber of solar drying system were measured by using computer based data acquisition system (Tempscan 1100, IOtech, Inc., Cleveland, USA). During drying period of $32 \mathrm{~h}$, ambient and drying air temperatures were $20.0 \pm 8.6^{\circ} \mathrm{C}$ and $37.2 \pm 6.9^{\circ} \mathrm{C}$ respectively. Data logger (LI-1400, LI-COR, Inc., Lincoln, USA) attached with a pyranometer sensor was used to measure the solar radiation incident on the evacuated tubular solar collector.

Figure 5 shows the variations of ambient air temperature, drying air temperature inside the chamber of solar drying system, and solar irradiance during drying test. It indicates that the solar irradiation has a direct effect on ambient air temperature and drying air temperature inside the chamber of solar drying system. Thus, an auxiliary heater of solar drying system was operated during from sunset to sunrise. In this study, auxiliary heater of drying system was turned on at 18:00 and turned off at 9:00 in the next day and turned on again at 18:00. Water in the storage tank was heated for $15 \mathrm{~h}$ by an auxiliary heater during the drying period of $32 \mathrm{~h}$.

Air velocity on the shelf inside the drying chamber measured by an anemometer (Model 24 - 6111, Kanomax, Inc., Osaka, Japan) was $0.8 \mathrm{~m} / \mathrm{s}$. Relative humidity inside the chamber of solar drying system was calculated by measuring the dry and wet bulb temperatures, and it was $24 \pm 4 \%$ RH.

Drying experiments were also conducted at an indoors and outdoors. Air temperature and relative humidity were $21 \pm 5^{\circ} \mathrm{C}$ and $47.5 \pm 7.5 \%$ for indoor drying and $20 \pm 5^{\circ} \mathrm{C}$ and $55 \pm 25 \%$ for outdoor drying respectively. Experimental results obtained by using solar drying system were compared with those of natural dryings at an indoors and

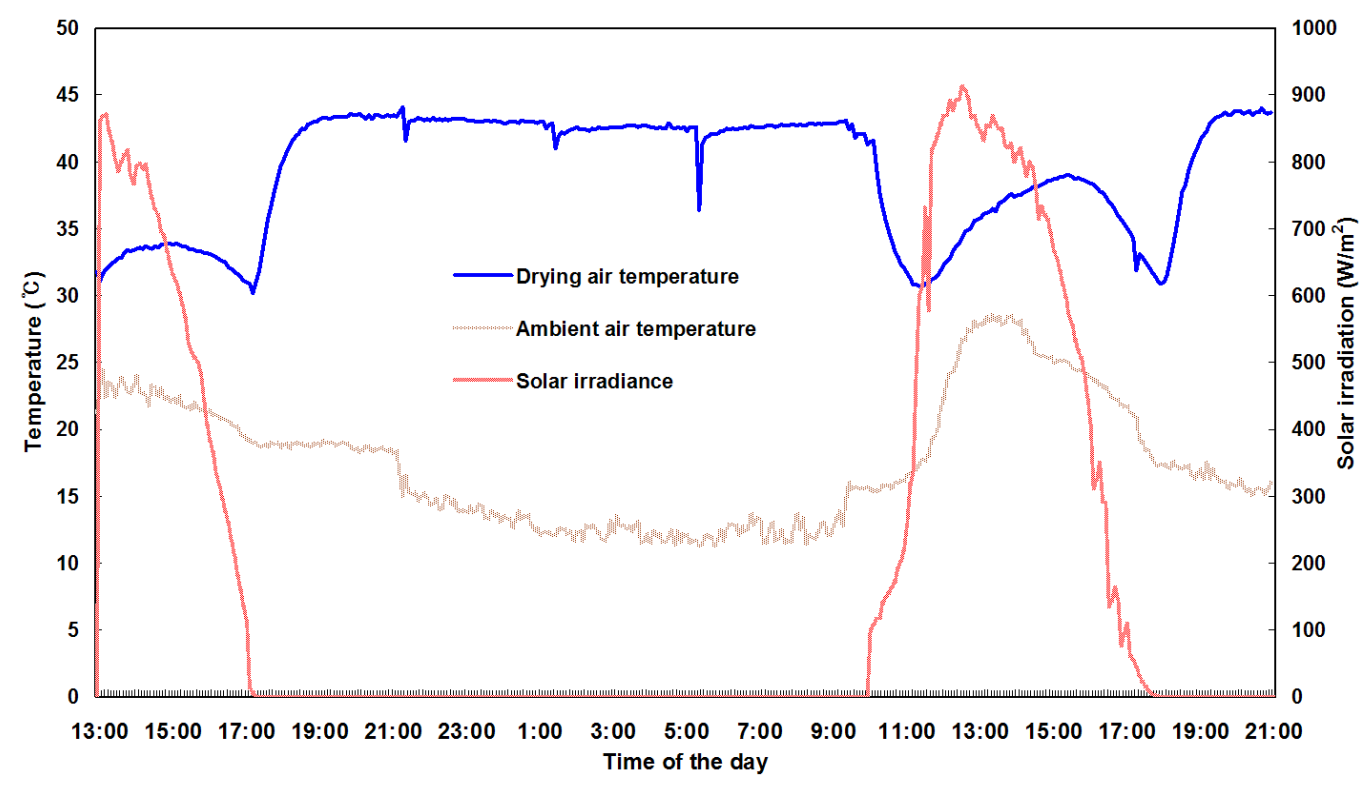

Figure 5. Variations of ambient air temperature, drying air temperature inside the drying chamber, and solar irradiance. 
Table 2. Half drying time of various drying materials for each drying method

\begin{tabular}{|c|c|c|c|c|}
\hline \multirow{2}{*}{ Drying method } & \multicolumn{4}{|c|}{ Half drying time $(h)$} \\
\hline & Carrot & Radish & Potato & Oyster Mushroom \\
\hline Drying system & $5.7 \pm 0.2$ & $6.8 \pm 0.1$ & $6.8 \pm 0.2$ & $2.5 \pm 0.1$ \\
\hline Outdoor drying & $16.0 \pm 0.4$ & $20.5 \pm 0.6$ & $20.3 \pm 0.5$ & $2.5 \pm 0.1$ \\
\hline Indoor drying & $33.0 \pm 0.6$ & $34.9 \pm 0.7$ & $33.8 \pm 0.8$ & $10.4 \pm 0.3$ \\
\hline
\end{tabular}

outdoors.

Radish, potato, carrot, and oyster mushroom were used as experimental materials. Radish, potato, and carrot were cut in the square as the size of $1 \times 1 \times 1 \mathrm{~cm}$, and oyster mushroom was sliced in a bit of $1 \pm 0.1 \mathrm{~g}$ weight. The mass of product used in drying experiments was $120 \mathrm{~g}$ by tray. Samples were uniformly spread evenly on a drying tray, and then they were placed on the shelf of the drying chamber, on the table in the room, and on the rooftop of an outdoors. During the night time, experimental materials for outdoor drying were covered with plastic paper to prevent the absorption of moisture from ambient air. Each sample on a tray was also weighed on an electronic balance (FA-3000KV, A\&D Co., Tokyo, Japan) every 4 hours. The experiments were repeated five times with reproducible results.

Five samples of each $40 \mathrm{~g}$ were used to determine the initial moisture content in an air oven at $103{ }^{\circ} \mathrm{C}$ for $25 \mathrm{~h}$. After drying, the sample masses were measured after cooling in a desiccator in $30 \mathrm{~min}$. Initial moisture contents for samples of carrot, radish, potato, and oyster mushroom were $1,080 \%$ (d.b.), 1,847\% (d.b.), 568\% (d.b.), and 1,024\% (d.b.) respectively.

\section{Results and Discussion}

The average moisture content, $M$ (d.b.), of drying sample at time, $t$ can be transformed to the dimensionless parameter of moisture ratio, $M R$ as follows:

$$
M R=\frac{M-M_{\mathrm{e}}}{M_{\mathrm{o}}-M_{\mathrm{e}}}
$$

Because the values of the equilibrium moisture content, $M_{e}$ are relatively small to $M$ or initial moisture content, $M_{o}$, the dimensionless moisture ratio, $M R$, of above equation can be simplified to $M / M_{o}$ (Doymaz, 2004). In this study, $M_{e}$ in the case of solar drying system was $0.19,0.21,0.09$, and 0.04 for each sample of carrot, radish, potato, and oyster mushroom. Thus, the moisture ratio $(M R)$, which is the ratio of instantaneous moisture content, $M$, on dry basis at drying time, $t$, over the initial moisture content, $M_{o}$, on dry basis is plotted against drying time $(t)$ in these drying curves.

Table 2 presents the half drying time of various drying samples for each drying method. Figure 5 shows the characteristic drying curves of moisture ratio $(M R)$ versus drying time $(t)$ for carrot, radish, potato, and oyster mushroom for each drying method. Half drying time ( $M R$ $=0.5$ ) is defined as the drying time which initial moisture content of drying sample is reduced to $50 \%$. It was used as the basis on evaluating an efficiency of solar drying system in comparison with indoor and outdoor dryings.

Outdoor drying for carrot, radish, and potato showed great drying effect on the initial period of drying before the half drying time. In initial drying period of outdoor drying, it might be considered that moisture from outer surface of drying materials was easily evaporated by sun radiation and wind with affecting on drying greatly. Overall, the half drying time was considerably reduced for all of drying samples dried in solar drying system. However, outdoor drying on reducing the half drying time was more effective than indoor drying for all of drying materials. In outdoor drying, each half drying time of carrot, radish, potato, and oyster mushroom was shortened by $17,14.4,13.5$, and $7.9 \mathrm{~h}$ compared with that of indoor drying.

In solar drying system, the half drying time of carrot, radish, and potato was reduced to about $1 / 3$ and $1 / 5$ in comparison with that of each outdoor and indoor drying. Solar drying system and outdoor drying for oyster mushroom showed the same half drying time. Oyster mushroom could be dried easily under outdoor environmental conditions with solar radiation and wind until $M R$ was reached to about 0.2 which means drying of $80 \%$ in comparing with initial moisture content. However, solar drying system showed great effect on drying for most samples compared with indoor and outdoor dryings during the latter drying period of $M R<0.5$, because of 

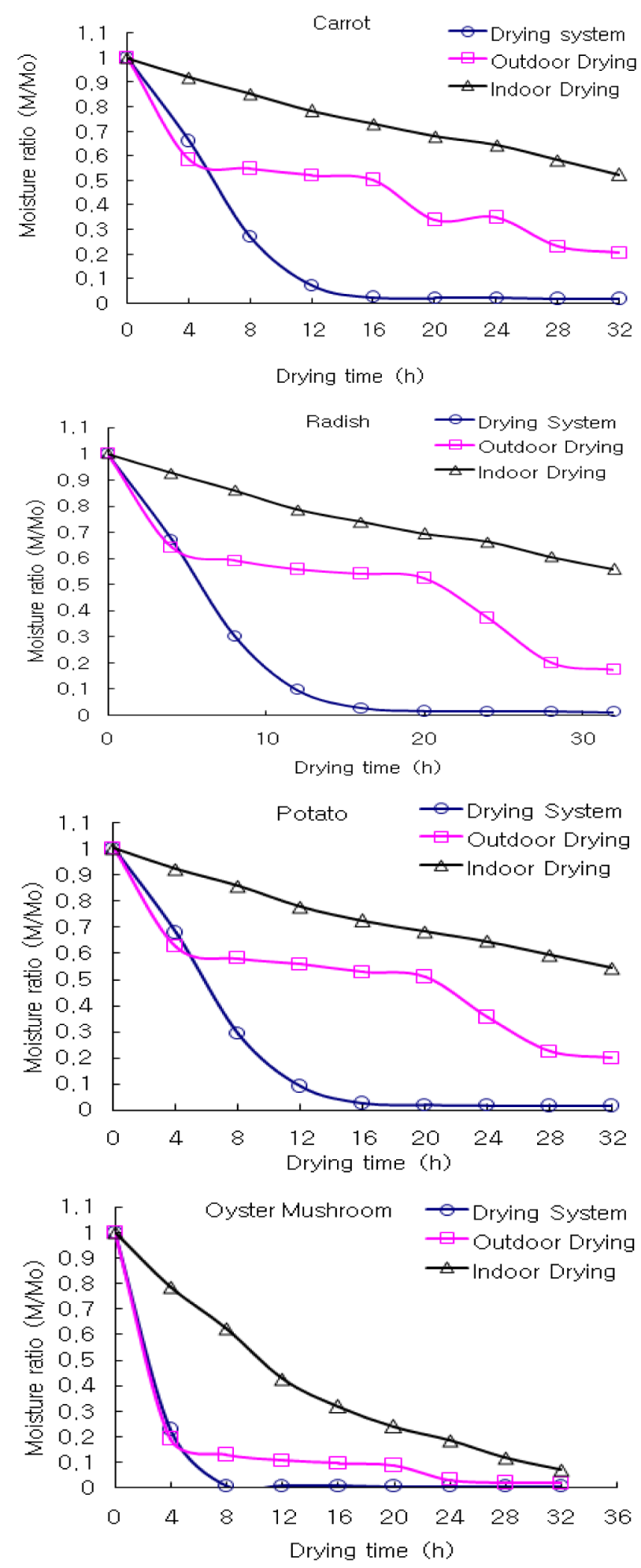

Figure 6. Operational flowchart for vegetable transplanting robot.

auxiliary heater during night.

In this study, an economic value of solar drying system was evaluated in comparison with hot air dryer worked with petroleum oil. If it is assumed that a time of drying is
$30 \mathrm{~h}$ and drying is performed 20 times for a year, it is estimated that operation of solar drying system for two years is economically valuable.

\section{Conclusions}

Overall, solar drying system showed considerable effect on reducing the half drying time for all of drying samples. However, outdoor drying was more effective than indoor drying on shortening the half drying time for all of drying materials. Solar drying system and outdoor drying for oyster mushroom showed the same half drying time. It is considered that oyster mushroom could be dried easily under outdoor environmental conditions with solar radiation until $M R$ was reached to about 0.2 . Solar drying system showed great effect on drying for most samples compared with indoor and outdoor dryings during the latter drying period of $M R<0.5$, because of auxiliary heater.

\section{Conflict of Interest}

No potential conflict of interest relevant to this article was reported.

\section{Acknowledgment}

This study was supported by the Research Grant from Kangwon National University.

\section{References}

Bakker-Arkema, F. W., J. DeBaerdemaeker, P. Amirante, M. Ruiz-Altisent and C. J. Studman. 1999. CIGR handbook of agricultural engineering. American Society of Agricultural Engineers, MI, USA.

Basunia, M. A. and T. Abe. 2001. Thin-layer drying characteristics of rough rice under natural convection. J. of Food Engineering 47:295-301.

Carvalho, M. J., M. Collares-Pereira, J. Correia de Oliveira, J. Farinha Mendes, A. Haberele and V. Wittwer. 1995. Optical and thermal testing of a new 1.12X CPC solar collector. Solar Energy Materials and Solar Cells 37:175-190. 
Doymaz, I. 2004. Convective air drying characteristics of thin layer carrots. J. Food Engineering 61:359-364.

El-Sebaii, A. A., S. Aboul-Enein, M. R. I. Ramadan and H. G. El-Gohary. 2002. Experimental investigation of an indirect type natural convection solar dryer. Energy Conversion \& Management 43:2251-2266.

Keey, R. B. 1992. Drying of looses and particulate materials. USA: Hemisphere Publishing Corporation.

Lin, Q. and S. Furbo. 1998. Solar heating systems with evacuated tubular solar collector. In Proc. of the
Eurosun '98 Conf. on CD-ROM. Portoroz, Slovenia.

Midilli, A. and H. Kucuk. 2003. Mathematical modeling of thin layer drying of pistachio by using solar energy. Energy Conversion \& Management 44:1111-1122.

Morrison, G. L. 2001. Solar collectors. In Solar Energy: The Sate of the Art, 145-221. Germany, ISES.

Morrison, G. L., I. Budihardjo and M. Behnia. 2004. Waterin-glass evacuated tube solar water heaters. Solar Energy 76:135-140. 